Sri Lanka J. Aquat. Sci. 17 (2012): 35-46

\title{
Diversity and density of sea urchins populations in rocky shores off Nilwella in Southern province of Sri Lanka
}

\author{
M.A. GAYASHAN and S. JAYAKODY* \\ Department of Aquaculture and Fisheries, Wayamba University of Sri \\ Lanka, Makandura, Gonawila, Sri Lanka \\ *Correspondence (sevvandi_jayakody@yahoo.com)
}

\begin{abstract}
Sea urchins (or regular echinoids) are one of the most common macro-grazers and keystone species in rocky shore systems. However, their ecology is little explored in Sri Lankan waters. Therefore, a study was conducted to investigate the spatiotemporal variations in the diversity and density of sea urchins off Nilwella in the Southern coast of Sri Lanka. Duwagahawella harbour area and Hirikatiya bay area were selected as disturbed and less disturbed areas respectively considering the presence and absence of a harbour and other anthropogenic impacts. Random permanent strip transects of varying lengths $(11-20 \mathrm{~m} \times 0.5 \mathrm{~m})$ were used to estimate the number of sea urchins for 5 months with 20 repeated weekly samplings. Sea urchin density and diversity were estimated for two sites and means were compared. According to the results, a total of 8 sea urchin species were detected from the two areas. Stomopneustes variolaris was the dominant species in both areas. The mean density of Stomopneustes variolaris was significantly higher in disturbed area compared to the less disturbed area $(P<0.05)$. However compared to disturbed area, densities of Tripneustes gratilla, Diadema setosum, Diadema savignyi, Echinostrephus molaris and Echinometra mathaei were higher $(P<0.05)$ in less disturbed area. Throughout the sampling, Shannon Weinner index of diversity was higher in less disturbed area $(P<0.05)$. Results highlighted the dominance of $S$. variolaris particularly in disturbed area. Further studies are necessary to establish the competitiveness of $S$. variolaris and if it out-competes the other associated sea urchin species.
\end{abstract}

Keywords: sea urchins, diversity, density, disturbance, rocky shores

\section{Introduction}

Sea urchins are one of the most common macro-grazers and key stone species in rocky shore system (Cebrian and Uriz 2006, Abraham 2007) and occasionally their grazing rates exceed sea grass growth rates resulting overgrazing (Eklof et al. 2008). They are also known for their role as bio-eroders of rocky shores (Asgaard and Bromley 2008). 
Population density and distribution of sea urchin can vary with both time and space (McClanahan et al. 2009; Nordemar et al. 2007). Spatial distribution and density of urchins are affected by the physical nature of substrate (Dumas et al. 2007), vegetation (Benitez-Villalobos et al. 2008), season (Alvarado 2008) and even by climatic events such as El-Niño (Attrill and Kelmo 2007). Recent studies have also indicated the changes in sea urchin distributions due to human influences (Matranga and Yokota 2008, Dupont et al. 2010). Especially the effects of pollutants on sea urchin have been studied and the results have indicated abnormalities in embryonic development (Kobayashi and Okamura 2002, 2004), decreased fertilization (Arizza et al. 2009) and growth reduction (Arslan et al. 2009).

At present Sri Lankan coastal belt is going through rapid transformations due to settlements, tourism, port construction (IUCN 2009) and coastal pollution. Since the diversity of many invertebrates has not been recorded, any changes that could happen due to above mentioned disturbances also go unnoticed. Despite their ecological importance, sea urchins in coastal areas have also received less attention in marine studies. Therefore, a study was conducted to understand the responses of diversity and density of sea urchin in a relatively disturbed and a less disturbed rocky shore of Southern province.

\section{Study area and Methodology}

Study was carried out in two selected sites of Southern Province in Nilwella area from November 2010 to February 2011. Duwagahawella harbour $\left(5^{\circ} 57^{\prime} \mathrm{N}\right.$ and $80^{\circ}$ $42^{\prime}$ E) was selected as a relatively disturbed area due to the presence of a fishing harbour that accommodates around 50 multiday boats and other fishing crafts and tourist resorts in the vicinity. It is also a popular bathing spot of both locals and foreigners. Hirikatiya bay $\left(5^{\circ} 57^{\prime} \mathrm{N}\right.$ and $\left.80^{\circ} 43^{\prime} \mathrm{E}\right)$, a secluded small bay was selected as a less disturbed area where around 10 non-mechanized traditional catamarans were in operation for pelagic fish and lobsters. In addition, about five females use the beach to bury coconut husks, a traditional method of extracting fibre for coir industry. The underlying rocky reef is shallow and very close to shore in both the locations and is exposed during low tide.

In both areas four random sites were selected and permanent plot transects were established on rocky shores. This was done by taking the distance to nearest land marks and the angle of the two ends of each transect to the land marks using a compass. A GPS (Garmin 78S) was also used to measure the longitude and latitude of the two ends of each transects. All transects were laid parallel to the coast and lengths varied from $11 \mathrm{~m}$ to $20 \mathrm{~m}$. At the time of data collection, a quadrate of $0.5 \times 0.5 \mathrm{~m}$ was swept along the transect holding from the middle thus forming a plot of $0.5 \mathrm{~m}$ width. Since it is not possible to make permanent plots underwater in rocky shores, moving plot transect method was adopted as in other studies (Bakus 2007). All the sea urchins present within the plots were counted every two weeks and were identified to species level using an online echinoid directory of British Natural History Museum, UK. Sampling was repeated weekly during the study period. In 
M.A. Gayashan and S. Jayakody/Sri Lanka J. Aquat. Sci. 17 (2012): 35-46

addition to permanent transects, the rocky shore of both areas were beach combed every 2 weeks at low tide in order to record sea urchins outside the transects to ascertain the true diversity.

Mean densities of sea urchins were compared between Duwagahawella harbour area and Hirikatiya bay area using two sample t-tests. Shannon Wiener Index (Magurran 2004) and Sorenson Similarity Index (Kent and Coker 1992) were computed and were compared between two selected study sites.

\section{Results}

A total of 8 sea urchin species belonging to five (05) Families were identified (Table 1).

Table 1. Shallow water sea urchins identified from Duwagahawella and Hiriketiya areas

\begin{tabular}{lll}
\hline Order & Family & Species name \\
\hline Stirodontia & Stomopneustidae & Stomopneustes variolaris \\
Aulodonta & Diadematidae & $\begin{array}{l}\text { Diadema setosum } \\
\text { Diadema savignyi }\end{array}$ \\
& & Tripneustes gratilla \\
Camrodonta & Toxopneustes & Echinostrephus molaris \\
& Echinometridae & Echinometra mathaei \\
& & Salmacis spp. \\
\hline
\end{tabular}

Stomopneustes variolaris was the most abundant sea urchin species in both the areas (Figure 1) and remained so throughout the study period (Figure 2). A relatively higher density of $S$. variolaris $(5.87 \pm 0.262)$ was present in disturbed Duwagahawella harbour area compared to the less disturbed Hiriketiya bay area $(2.05 \pm 0.073)$ (t-test, $d f=38, P<0.05)$. 


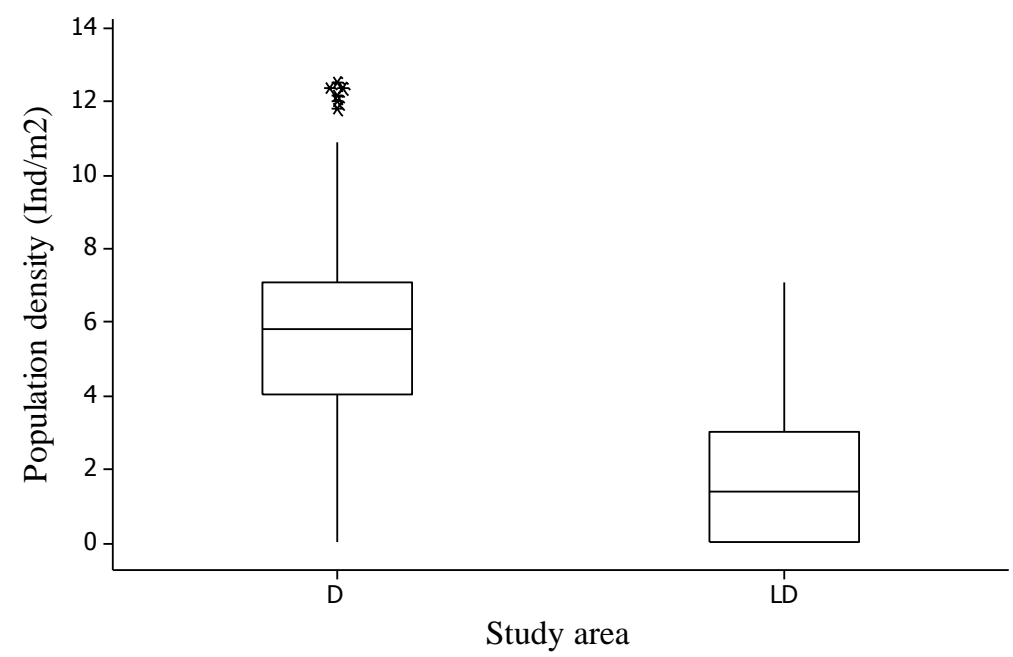

Figure 1. Population density (Ind./ $\mathrm{m}^{2}$ ) of Stomopneustes variolaris in disturbed (D) and less disturbed (LD) areas.

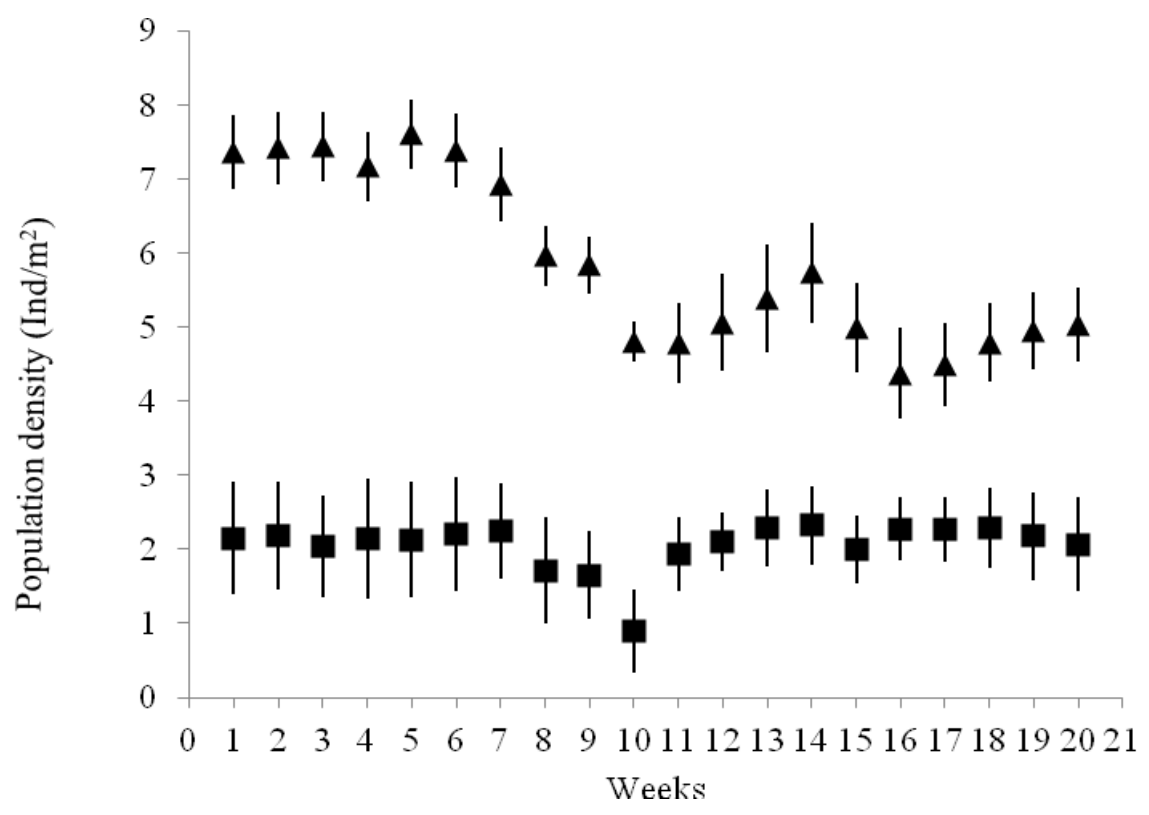

Figure 2. Fluctuations of average population density (Ind. $/ \mathrm{m}^{2} \pm \mathrm{SE}$ ) of Stomopneustes variolaris in disturbed (depicted in triangles) and less disturbed (depicted in squares) areas.

However, density of Tripneaustes gratilla was higher in less disturbed Hiriketiya bay area $(0.52 \pm 0.0421)$ compared to disturbed Duwagahawella harbour 
M.A. Gayashan and S. Jayakody/Sri Lanka J. Aquat. Sci. 17 (2012): 35-46

area $(0.11 \pm 0.025)$ (t-test, $d f=38, P<0.05$ ) (Figures 3 and 4). Diadema setosum and Diadema savignyi were present in less disturbed Hiriketiya bay area only (Figures 5, 6 and 7).

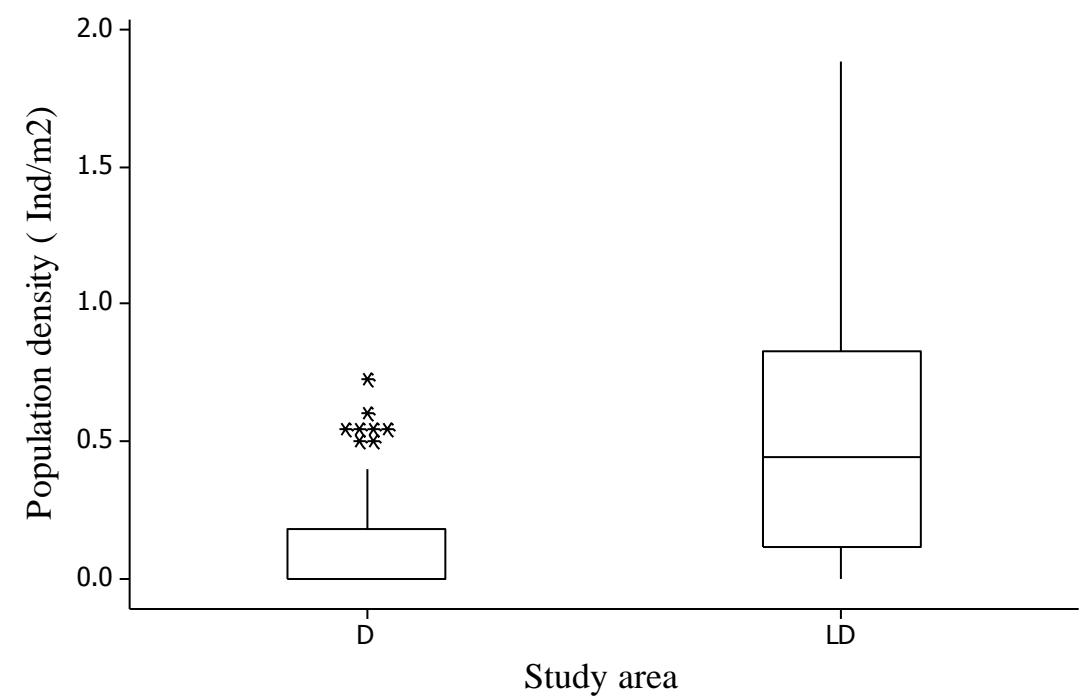

Figure 3. Population density of Tripneustes gratilla in disturbed (D) and less disturbed (LD) areas.

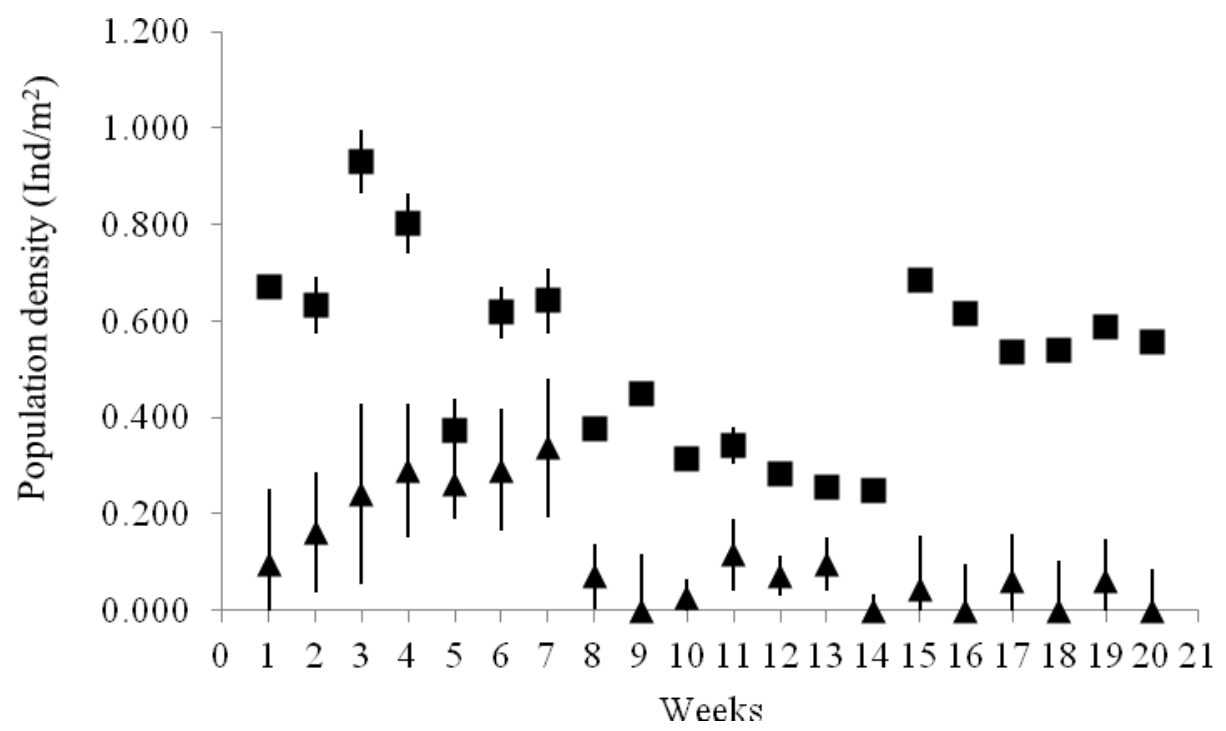

Figure 4. Fluctuations of population density (Ind. $/ \mathrm{m}^{2} \pm \mathrm{SE}$ ) of Tripneustes gratilla in both disturbed (depicted in triangles) and less disturbed (depicted in squares) areas. 
M.A. Gayashan and S. Jayakody/Sri Lanka J. Aquat. Sci. 17 (2012): 35-46

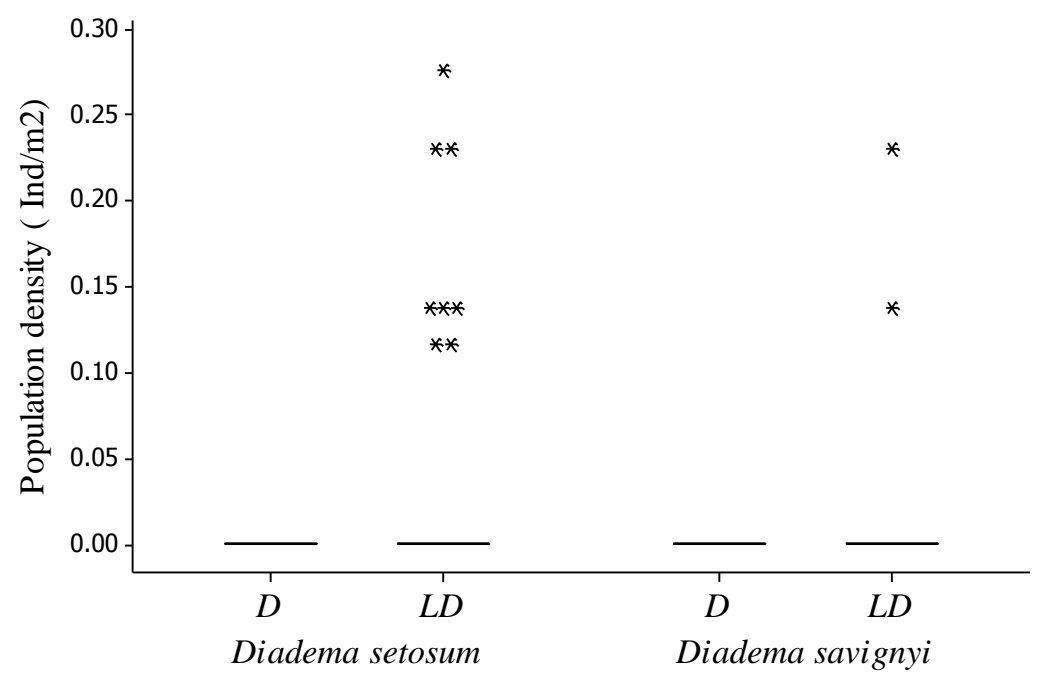

Figure 5. Population densities of Diadema setosum, and D. savignyi in disturbed (D) and less disturbed (LD) areas.

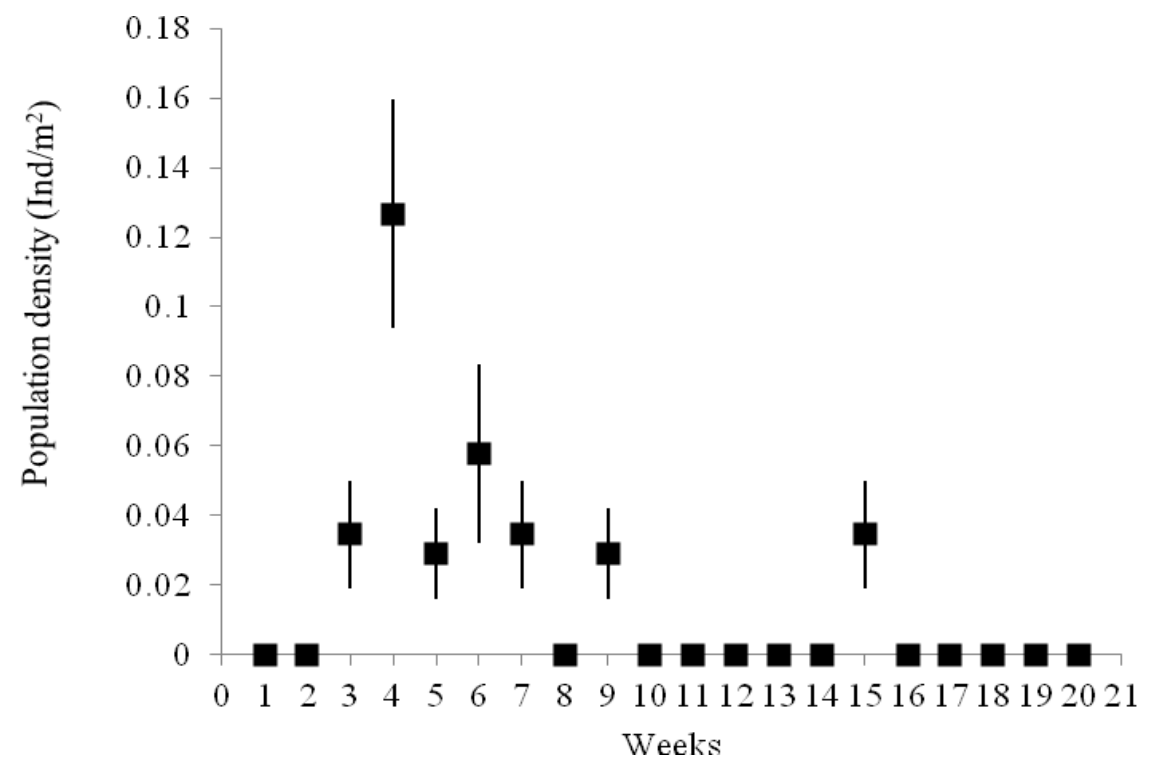

Figure 6. Fluctuation average population density (Ind./ $\left.\mathrm{m}^{2} \pm \mathrm{SE}\right)$ of Diadema setosum in less disturbed area. 
M.A. Gayashan and S. Jayakody/Sri Lanka J. Aquat. Sci. 17 (2012): 35-46

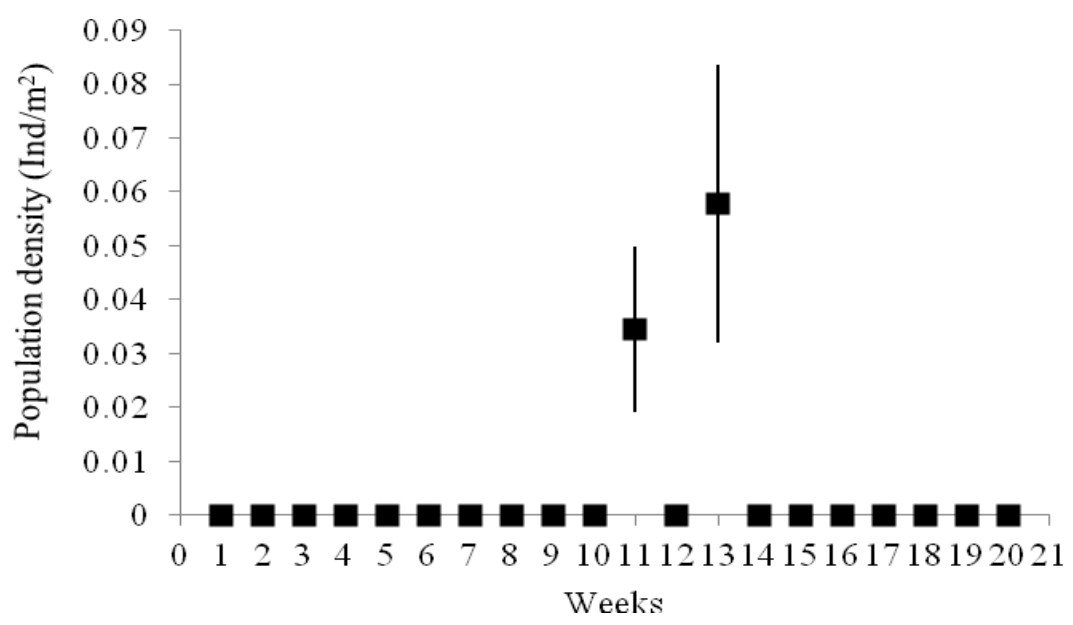

Figure 7. Fluctuation average population density (Ind. $/ \mathrm{m}^{2} \pm \mathrm{SE}$ ) of Diadema savignyi in less disturbed area.

Echinotrephus molaris and Echinometra methaei were both absent in disturbed area (Figure 8). E. molaris which is a rock burrowing species was detected in 8th week in the less disturbed area and their density was constant thereafter until the end of study period (Figure 9). Similarly E. methaei was detected in 11 th week in less disturbed area at a density of $(0.028 \pm 0.009)$ which fluctuated thereafter (Figure 10).

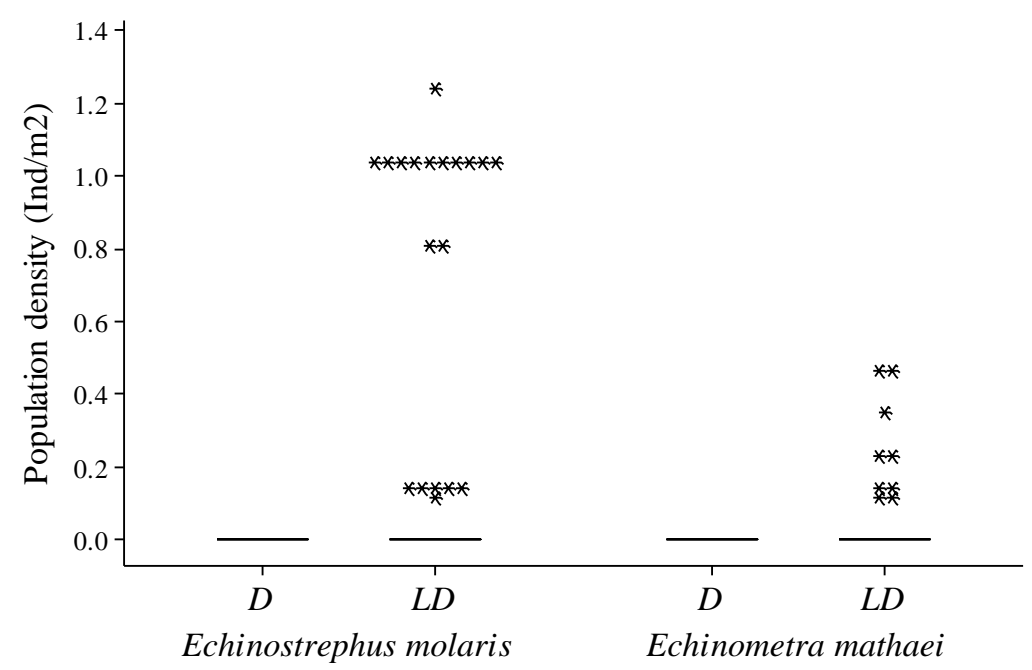

Figure 8. Population densities of Echinostrephus molaris and Echinometra mathaei in disturbed (D) and less disturbed (LD) areas. 


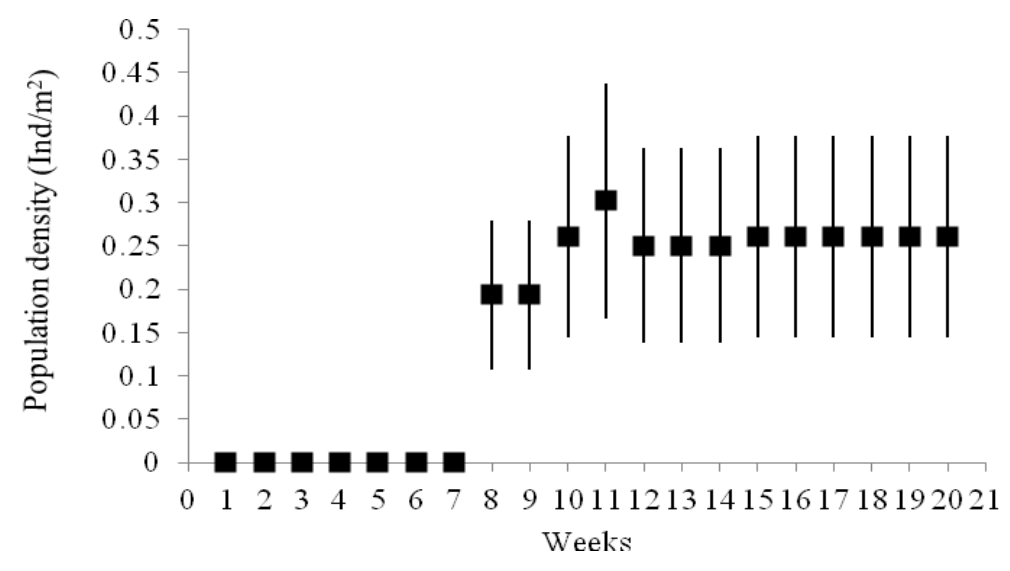

Figure 9. Fluctuations average population density (Ind. $/ \mathrm{m}^{2} \pm \mathrm{SE}$ ) of Echinostrephus molaris in less disturbed area.

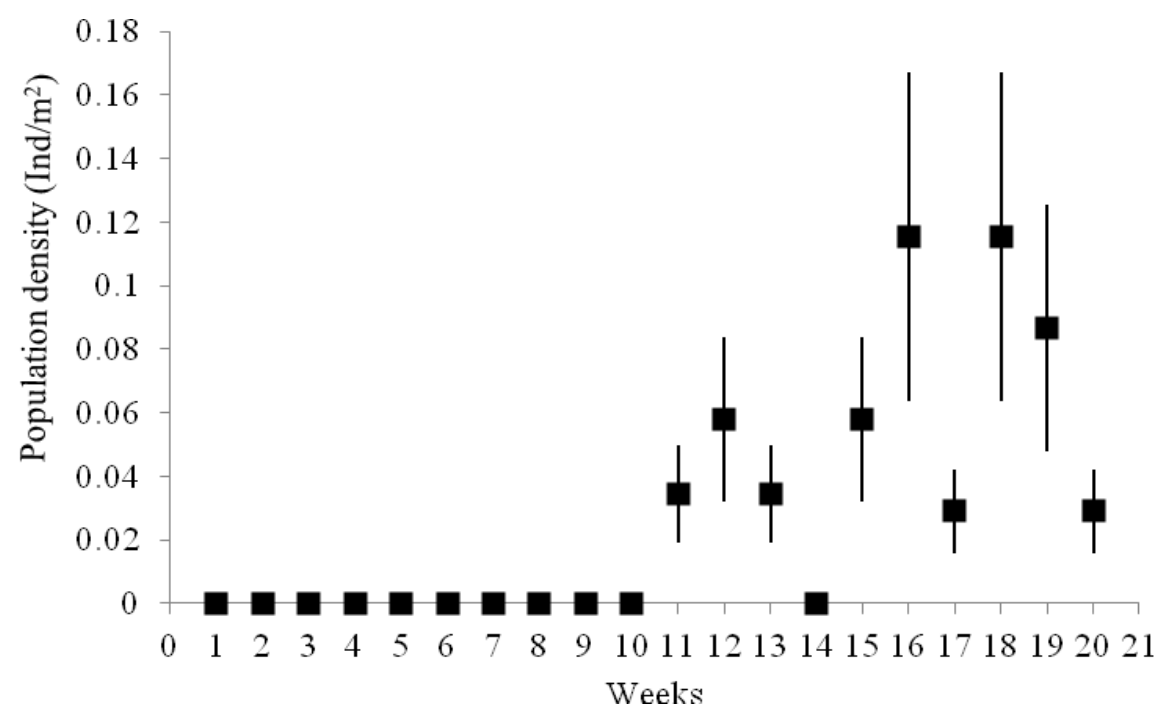

Figure 10. Fluctuations average population density (Ind. $/ \mathrm{m}^{2} \pm \mathrm{SE}$ of Echinometra mathae i in less disturbed area.

Mean Shannon-Weiner index of diversity in less disturbed Hiriketiya bay area was significantly higher $(0.414 \pm 0.024)$ compared to disturbed Duwagahawella harbour area $(0.0570 \pm 0.012)$ throughout the study period (t-test, $d f$ $=38, P<0.05$ ) (Figure 11). Sorenson's Index of Similarity indicated distinctions between two sites towards the latter part of the study (Figure 12). 
M.A. Gayashan and S. Jayakody/Sri Lanka J. Aquat. Sci. 17 (2012): 35-46

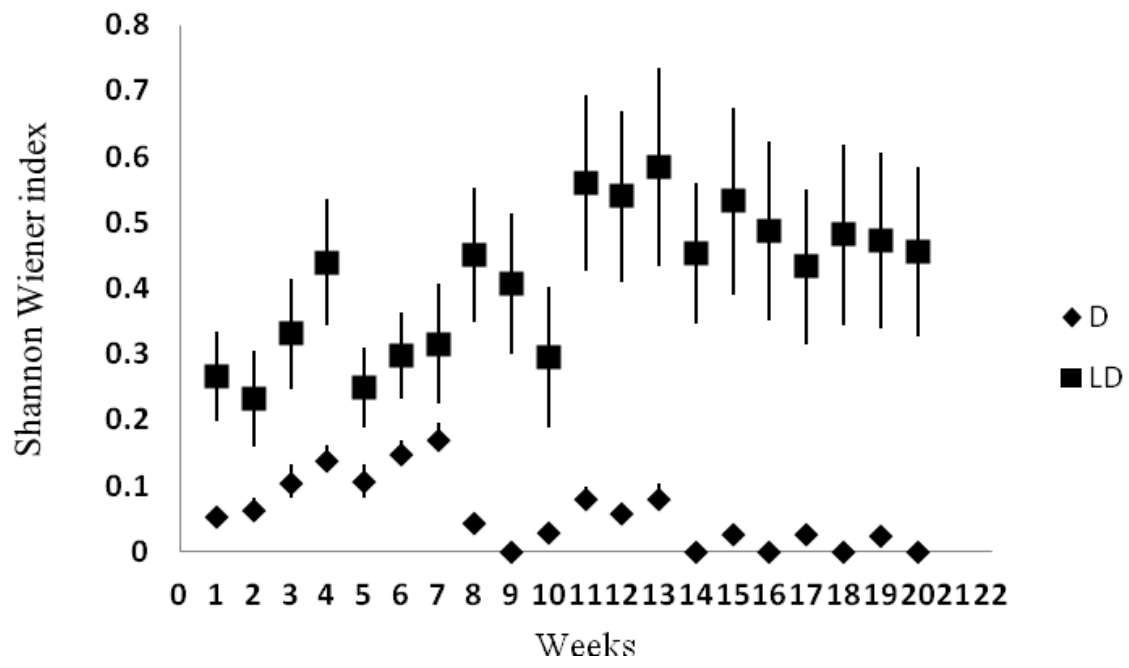

Figure 11. Fluctuations in Shannon Wiener index in disturbed and less disturbed area.

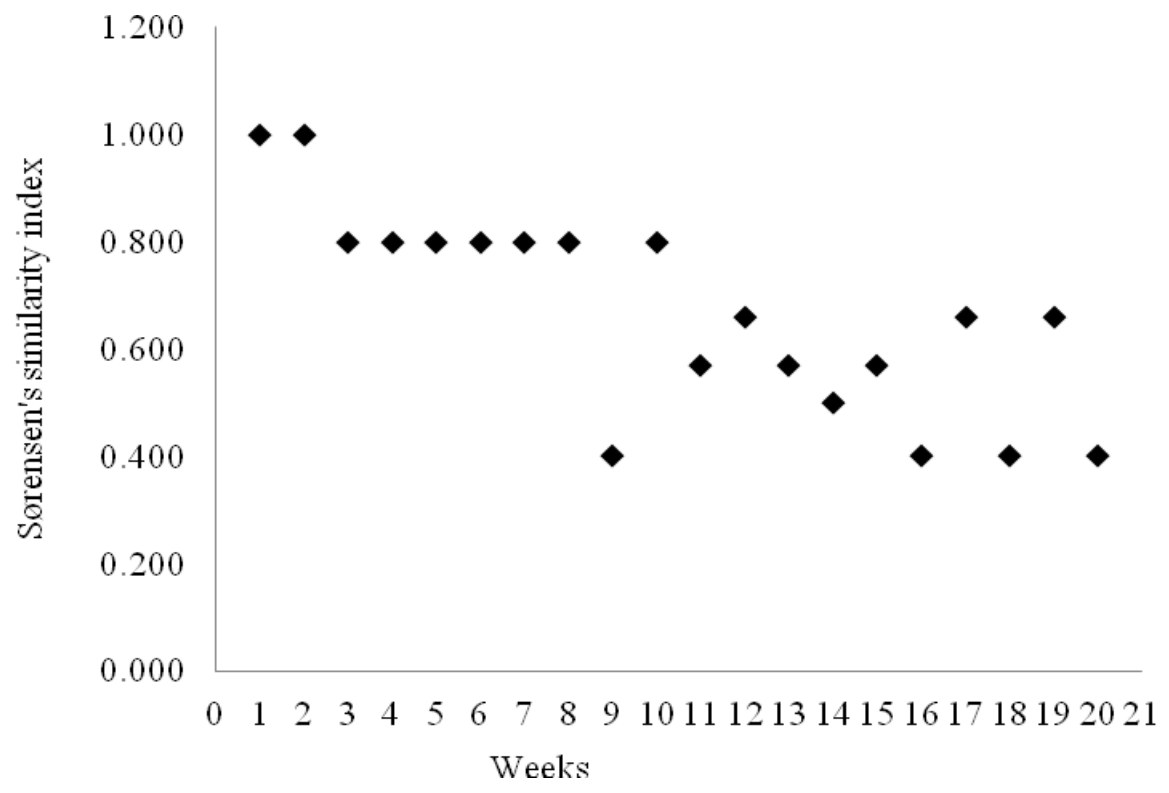

Figure 12. Fluctuations of Sorenson's Similarity Index of regular echinoids in rocky shores. 


\section{Discussion}

Human disturbance is blamed for changes in biodiversity of both aquatic and terrestrial systems (Magurran 2004; Yokota and Matranga 2010). Because of its vastness and three dimensional properties most changes that happen in aquatic systems specially in sea, goes unnoticed (Garrison 2009). However, sea water being the moving mass that binds all continents, understanding such changes in marine environments is vital. Current study attempted understanding the responses in terms of diversity and abundance of coastal sea urchins to human disturbances.

Studies have indicated that sea urchin density and distribution is affected by the nutrient availability and as such colder upwelling months have been found to support aggregation for species like Astropyga pulvinata (Alvarado 2008). Current results indicated either $S$. variolaris not being affected or being facilitated by disturbance as in disturbed Duwagahawella harbour area its population was flourishing to a level where some rocks were totally covered with only this species. This phenomenon has been noticed elsewhere specially for Diadema antillarum where populations increased under stress conditions (Attrill and Kelmo 2007) while other echinoids decline. Our results also indicated the dominance of $S$. variolaris in disturbed area and the decline of other regular echinoids. This may suggest that few species are able to withstand the changes due to disturbance and to expand into vacant niches that are created by the decline of sensitive echinoids. Since the two study areas are close to each other and are influenced by the same oceanographic conditions, Hiriketiya bay supporting a higher diversity could be due to low disturbance compared to Duwagahawella harbour area. The decline of some echinoids from disturbed areas is a concern as sea urchins are known to create specific niches among their spines for other species such as crabs (De Bruyn et al. 2009).

Population boom of some sea urchin species has been seen as a positive effect in areas where degraded coral reefs are present. When degradation is due to elevated levels of nutrients which increase algal growth, echinoids have been identified to recreate algae free areas facilitating coral growth (Walters et al. 2009). Nevertheless, Cebrian and Uriz (2006) mentioned that such urchin fronts also facilitate rock borers such as sponges thus weakening the rocky substrate. Hence, it is evident that urchins being keystone species in rocky shores of shallow coastal waters, could affect the dynamics of the entire habitat thus they can be considered as good candidates to assess the health of rocky shores (Barrett et al. 2009).

Although the current study suffers from lack of a broad spatial and temporal coverage, the results are supporting outcomes from similar studies where dominance of some sea urchins and their increased populations changing the rocky and reef ecosystems (Eklof et al. 2008). The environmental factors that affect the spatial distribution and diversity of sea urchins needs to be studied in detail as small scale heterogeneity is considered as an important factor (Dumas et al. 2007) and such heterogeneity could easily be created by human disturbance. 
M.A. Gayashan and S. Jayakody/Sri Lanka J. Aquat. Sci. 17 (2012): 35-46

\section{References}

Abraham, E. R. 2007.

Sea-urchin feeding fronts. Ecological Complexity, 4, 161-168.

Alvarado, J. J. 2008.

Seasonal occurrence and aggregation behaviour of the sea urchin Astropyga pulvinata (Echinodermata : Echinoidea) in Bahia Culebra, Costa Rica. Pacific Science, 62:579-592.

Arizza, V., G. Di Fazio, M. Celi, N. Parrinello \& M. Vazzana 2009.

Cadmium, Copper and Tributyltin effects on fertilization of Paracentrotus lividus (Echinodermata). Italian Journal of Animal Science 8: 839-841.

Arslan, O.C., H. Parlak, S. Katalay, M. Boyacioglu \& M.A. Karaslan 2009.

Embryotoxic effects of water and sediment from Nif Brook (Western Turkey) on sea urchin Paracentrotus lividus. Fresenius Environmental Bulletin 18: 663-664.

Asgaard, U. \& R. G. Bromley 2008.

Echinometrid sea urchins, their trophic styles and corresponding bioerosion.

In: Current developments in bioerosion (Wisshak M. \& L. Tapanila eds). pp. 279-303. Erlangen Earth Conference Series. Springer, Berlin.

Attrill, M. J. \& F. Kelmo 2007.

Opportunistic responses of Diadema antillarum (Echinodermata: Echinoidea) populations following the 1997-98 El Niño event in Bahia, Brazil. Estuarine Coastal and Shelf Science 73: 243-248.

Bakus, G.J. 2007.

Quantitative Analysis of Marine Biological Communities - Field Biology and Environment, John Wiley \& Sons, Inc., London.

Barrett, N. S., C.D. Buxton, \& G.J. Edgar 2009.

Changes in invertebrate and macro-algal populations in Tasmanian marine reserves in the decade following protection. Journal of Experimental Marine Biology and Ecology 370: 104-119.

Benitez-Villalobos, F., M. Gomez, \& R.A.L. Perez 2008.

Temporal variation of the sea urchin Diadema mexicanum population density at Bahias de Huatulco, Western Mexico. Revista De Biologia Tropical 56: 255-263.

Cebrian, E. \& M.J. Uriz 2006.

Grazing on fleshy seaweeds by sea urchins facilitates sponge Cliona viridis growth. Marine Ecology Progress Series 323:83-89.

De Bruyn, C., T. Rigaud, B. David \& C. De Ridder 2009.

Symbiosis between the pea crab Dissodactylus primitivus and its echinoid host Meoma ventricosa: potential consequences for the crab mating system. Marine Ecology Progress Series 375: 173-183.

Dumas, P., M. Kulbicki, S. Chifflet, R. Fichez \& J. Ferraris 2007.

Environmental factors influencing urchin spatial distributions on disturbed coral reefs (New Caledonia, South Pacific). Journal of Experimental Marine Biology and Ecology 344: 88-100. 
Dupont, S., O. Ortega-Martinez \& M. Thorndyke 2010.

Impact of near-future ocean acidification on echinoderms. Ecotoxicology 19: 449-462.

Eklof, J. S., M. De La Torre-Castro, M. Gullstrom, J. Uku, N. Muthiga, T. Lyimo \& S.O. Bandeira 2008.

Sea urchin overgrazing of sea grasses: A review of current knowledge on causes, consequences, and management. Estuarine Coastal and Shelf Science 79: 569-580.

Garrison, T. 2009.

Essentials of Oceanography, USA, Brooks/Cole Cengage Learning.

IUCN 2009.

Sri Lanka National Strategy and Action Plan Mangroves for the Future Programme. Sri Lanka Country Office, IUCN, Colombo.

Kent, M. \& P. Coker 1992.

Vegetation description and analysis: A practical approach, UK, Belhaven.

Kobayashi, N. \& H. Okamura 2002.

Effects of new antifouling compounds on the development of sea urchin.

Marine Pollution Bulletin 44: 748-751.

Kobayashi, N. \& H. Okamura 2004.

Effects of heavy metals on sea urchin embryo development. 1. Tracing the cause by the effects. Chemosphere 55: 1403-1412.

Magurran, A.E. 2004.

Measuring Biological Diversity. Blackwell Publishing, Oxford.

Matranga, V. \& Y. Yokota 2008.

Responses of marine organisms to physical and chemical impacts. Cell Biology and Toxicology 24: 471-474.

Mcclanahan, T.R., N.A. Muthiga, J. Maina, A.T. Kamukuru \& S.A.S. Yahya 2009.

Changes in northern Tanzania coral reefs during a period of increased fisheries management and climatic disturbance. Aquatic Conservation 19: 758-771.

Nordemar, I., G.L. Sjoo, E. Mork \& T.R. McClanahan 2007.

Effects of estimated herbivory on the reproductive potential of four East African algal species - a mechanism behind ecosystem shifts on coral reefs? Hydrobiologia 575: 57-68.

Walters, L.J., T. Turner, I.B. Kuffner, V.J. Paul, R. Ritson-Williams, K. Grablow, C. Settar, G. Rivera \& T.D. Hickey 2009.

Coral-Algal-Urchin Interactions in Caribbean Waters. Integrative and Comparative Biology 49: 321-321.

Yokota, Y. \& V. Matranga 2010.

Biodiversity for our future. Ecotoxicology 19: 445-448. 